\title{
Physiological characters in mixed martial arts
}

\author{
Petter Alm, Ji-Guo Yu* \\ Sports Medicine Unit, Department of Surgical and Perioperative Sciences, Umeå University, 90187 Umeå, Sweden
}

Email address:

pettr.alm@gmail.com(P. Alm), jiguo.yu@idrott.umu.se(J-G. Yu)

\section{To cite this article:}

Petter Alm, Ji-Guo Yu. Physiological Characters in Mixed Martial Arts. American Journal of Sports Science.

Vol. 1, No. 2, 2013, pp. 12-17. doi: 10.11648/j.ajss.20130102.11

\begin{abstract}
Mixed martial arts (MMA) is a relatively new sport and is a mixture of many different martial arts. Currently, study on the physiological characters in the sport is very limited. The present study evaluated the physiological characters in 5 active male MMA athletes at two occasions with one year between. Aerobic- and anaerobic capacity were estimated through measurement of $\mathrm{VO}_{2 \max }$ and anaerobic threshold using both treadmill running and arm cycling. Muscle strength was evaluated through series measurements. Body composition and personal competition records were also examined. The subjects presented above average aerobic capacity, but rather high anaerobic capacity and threshold levels compared with other similar sports. No significant difference in $\mathrm{VO}_{2 \max }$, anaerobic threshold or body composition was observed between the two test occasions, despite a decreased tendency in muscle strength/power in the second test compared to the first. The results were interpreted to indicate either the MMA athletes had reached the physiological requirements for MMA or the one year physical training was inefficient in further improving the parameters.
\end{abstract}

Keywords: Mixed Martial Arts, Physiological Characters, Aerobic Capacity, Anaerobic Capacity

\section{Introduction}

Modern Mixed Martial Arts (MMA) is a mixture combat sport including boxing, wrestling, Brazilian jiu-jitsu, muay Thai, kickboxing, taekwondo, karate, judo and other styles. MMA allows the use of both striking and grappling while in position of both standing and on the ground. MMA is a new sport with its first authorized competition in 1993 [Ultimate Fighting Championship (UFC)]. However, at that time it was more of human cockfight rather than a real sport, and the participants were from various martial arts with almost no rules. Nowadays, the sport has developed a lot of rules to ensure the safety of the fighters, and has its mainstream audience all over the world.

Even though the popularity of MMA is steadily growing, knowledge of the physiological characters on the sport are relatively few compared with other similar sports like rugby [1], wrestling [2,3,4] or judo [5]. To our knowledge, only one study has examined physiological characteristics in amateur MMA athletes [6]. The study, however, only estimated general physiological demands, not in reveal time MMA competition.

A formal MMA competition consists of 3 rounds with 5 minutes for each round and 1 minute rest between rounds while a title competition usually contains 5 rounds. Therefore, MMA stresses aerobic energy system [7] with respect to the total time of a competition (15 or 25 minutes). However, MMA athletes also utilized lactate energy system during both training and competition [8]. This is reasonable because of the highly competitive actions in each round.

In MMA there are many explosive actions such as kicking and striking, which are often critical for the final result of a competition. Therefore, muscle power of both upper and lower body is especially important in MMA.

In the present study, a group of 5 active male MMA athletes were tested in two occasions with one year in between. The tests included both aerobic and anaerobic systems. Body composition and muscle strength and power of both lower and upper body were also measured. We intended firstly to provide a physiological profile of MMA athletes. Secondly, by comparing the competition record of the subjects with the test results obtained at the two test occasions, we also aimed to evaluate whether the routine physical training was effective to improve competition record and/or physiological parameters.

\section{Material and methods}

\subsection{Subjects}

Five elite MMA fighters were recruited for the study. Detailed information of the subjects is listed in table 1 . 
Table 1. Data for age and anthropometry (Mean $\pm S D)$

\begin{tabular}{|c|c|}
\hline Age (Years) & $29,6 \pm 5,50$ \\
\hline Weight (kg) & $80,8 \pm 11,08$ \\
\hline Height $(\mathrm{cm})$ & $180,4 \pm 9,07$ \\
\hline
\end{tabular}

\subsection{Experimental Approach}

Physiological evaluation on the 5 subjects was performed at two separate occasions with one year in between. One subject did not perform the second test due to injury. All tests were conducted in the laboratory of Sports Medicine Unit at Umeå University.

Using a dual-emission x-ray absorptiometry (GE Lunar iDEXA DPX-L scanner, software version 1, 3y Madison, Wi, USA), all subjects were scan to determine their anthropometrics including bone mineral density, muscle mass, fat mass, fat percentage and muscle percentage . The reliability of the iDEXA has been proved early [9].

To measure $\mathrm{VO}_{2 \max }, \mathrm{VO}_{2}$ and heart rate at threshold level, the subjects were asked to run on treadmill and perform an arm cycling exercise. After a short standardized warm up, the subjects started running on a treadmill (Rodby, RL2500E, Sweden) with a start speed of $5 \mathrm{~km} / \mathrm{h}$. The speed was increased to $7 \mathrm{~km} / \mathrm{h}, 9 \mathrm{~km} / \mathrm{h}, 10,6 \mathrm{~km} / \mathrm{h}, 12 \mathrm{~km} / \mathrm{h}$ for every third min till exhausted. If the subjects were still not exhausted at the highest speed, the inclination of the treadmill would be raised by $2 \%$ every third minute till exhausted. Personal absolute and relative $\mathrm{VO}_{2 \max }$ and maximal heart rate were recorded during the running. Levels of $\mathrm{VO}_{2}$ and heart rate were measured at threshold level using ventilation switch point for $\mathrm{O}_{2}\left[\mathrm{VO}_{2}\right.$ at aerobic threshold (AT; vent)], ventilation switch point for $\mathrm{CO}_{2}$ $\left(\mathrm{VO}_{2}\right.$ at $\mathrm{AT}$, Wasserman), respiratory exchange ratio 1 (RER 1; $\mathrm{VO}_{2}$ at RER1), aerobic lactate threshold $(2 \mathrm{mMol} / 1$; $\mathrm{VO}_{2}$ at Lactate $2 \mathrm{mMo}$ ) and onset of blood lactate accumulation (4mMol/1; $\mathrm{VO}_{2}$ OBLA). Hemoglobin level and lactate recovery rate after the running were also measured using blood sample $(2 \mathrm{ml})$ taken from the right arm vein before every running speed, and at $0,3,5$ and 10 minutes after the running.

All the tests except the lactate AT tests were repeated using arm cycling. The height of the arm pedals (arm cycle Rodby RE990A, Sweden) was individually standardized to the subjects' intercostale 5. The work load started at 40 watt and increased 30 watt every third minutes till exhausted. For lactate recovery rate, a drop blood sample from the right middle fingertip was taken at $0,3,5$ and 10 minutes after the arm cycling.

Ventilation AT was measured using mixed chamber analyzer (Jaeger Oxycon Pro, Sweden). Heart rate was measured using a heart rate monitor (POLAR S610i, Finland). Lactate level and hemoglobin values were analyzed using blood analyzer (YSI 2300 STAT Plus, USA) [10].

After 20-30 minutes rest following the treadmill test all subjects were tested for squat jump (SJ), counter movement jump (CMJ), counter movement jump with arm swings
(CMJa) and vertical sit-ups. MuscleLab (V8.23) with an infrared contacted mat was used for jump tests.

Personal competition record calculated as percentage of win in total competitions before each test and one year before each test was counted.

\subsection{Data Analysis}

Statistical analyses were performed using SPSS Statistics (SPSS 20, Inc., and Chicago, IL, USA). Data was presented as mean \pm SD. Paired sample t-test was applied to data from the two tests. For the heart rate measurements, an independent sample t-test was used. Statistical significance was set at $\mathrm{p} \leq 0.05$.

\section{Results}

\section{1. $\mathrm{VO}_{2 \max }$ and $\mathrm{VO}_{2}$ and Heart Rate at Threshold Level}

Group values of $\mathrm{VO}_{2 \max }$, and $\mathrm{VO}_{2}$ and heart rate at threshold level measured with treadmill and arm cycle for both test occasions were shown in Figure 1-4. No significant difference (P $\square 0.05$ ) was observed in any of the variables between the two tests for either treadmill running or arm cycling. However, relative $\mathrm{VO}_{2 \max }(\mathrm{ml} / \mathrm{min} / \mathrm{kg})$ was significant higher $(p<0.05)$ at the first test compared to the second test for both treadmill running and arm cycling (appendix 1 and 2).

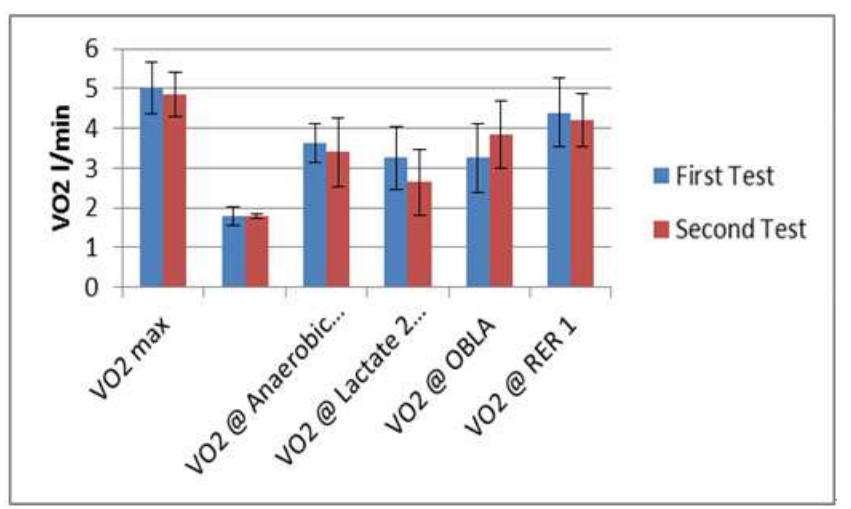

Figure1.VO⿰冫 $@$ threshold measured on treadmill

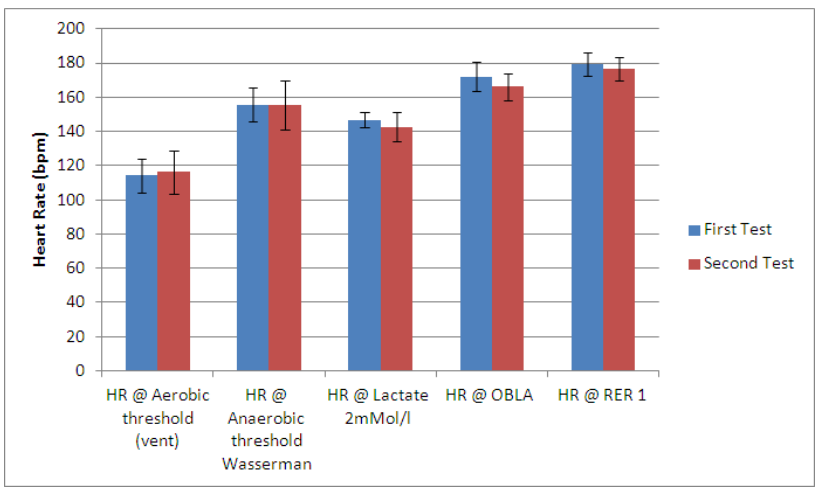

Figure 2.Heart rate@ threshold measured on treadmill 


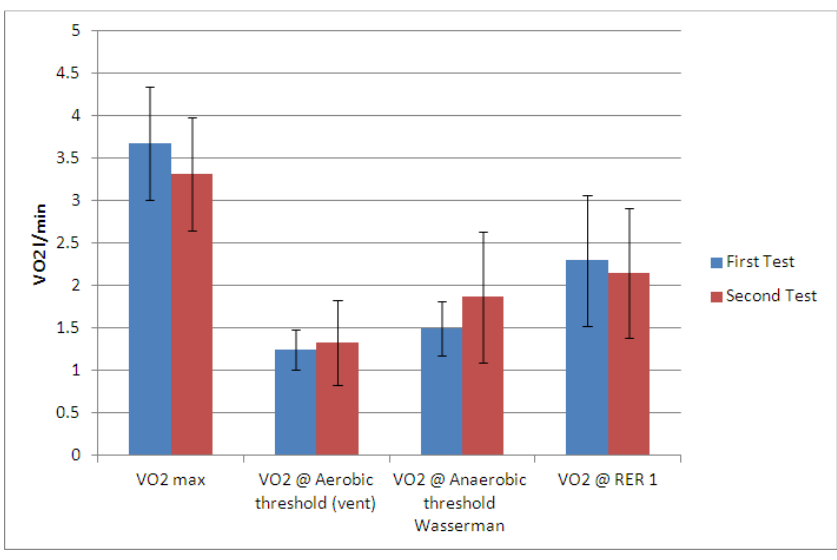

Figure3.VO2@ threshold measured on arm cycle

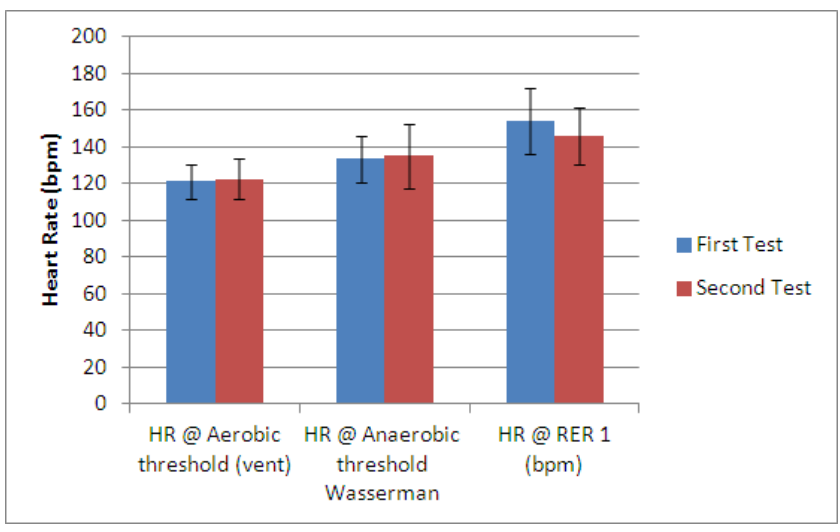

Figure 4. heart rate@ threshold measured on arm cycle

\subsection{Lactate Recovery Rate}

Results of lactate recovery rate were shown in Figure 5. Between the two test occasions, significant difference in lactate level [La] was only observed at 0 min after treadmill running (Figure 5; $<<0.05$ ). When comparing [La] values between the two test methods for both test occasions, significant difference $(\mathrm{p}<0.05)$ was only observed after the first test occasion at $10 \mathrm{~min}$.

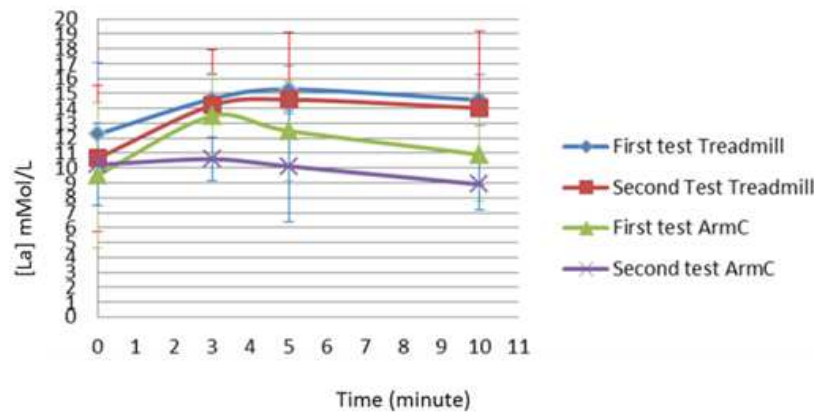

Figure 5. Lactate [La] recovery rate after the the two test ocasions with both treadmill and arm cykle

\subsection{Strength and Power Tests}

Results of the strength and power tests were shown in Table 2. Between the two test occasions, squat jump (cm) and counter movement jump with arm swing $(\mathrm{cm} / \mathrm{kg})$ were significant higher $(\mathrm{p}<0.05)$ at the first occasion than the second, and all the other measurements showed no significant difference between the two test occasions.

Table 2. Comparison of strength/power (Mean $\pm S D$ )

\begin{tabular}{cccc}
\hline & First test & Second test & P-value \\
\hline SJ (cm) & $40,3 \pm 3,78$ & $36,23 \pm 3,59$ & $0,02 \square$ \\
CMJ (cm) & $43,1 \pm 5,07$ & $41,25 \pm 2,13$ & 0,46 \\
CMJa (cm) & $50,18 \pm 5,63$ & $47,2 \pm 1,6$ & 0,31 \\
Vertical sit-ups (reps) & $22,25 \pm 3,78$ & $23,5 \pm 3,1$ & 0,34 \\
Hang Clean $(\mathrm{kg} / \mathrm{kg})$ & $1,09 \pm 0,07$ & $1,06 \pm 0,11$ & 0,22 \\
Deadlift $(\mathrm{kg} / \mathrm{kg})$ & $2,2 \pm 0,19$ & $2,12 \pm 0,3$ & 0,43 \\
Relative SJ $(\mathrm{cm} / \mathrm{kg})$ & $0,51 \pm 0,05$ & $0,46 \pm 0,05$ & 0,85 \\
Relative CMJ (cm/kg) & $0,55 \pm 0,04$ & $0,52 \pm 0,07$ & 0,15 \\
Relative CMJa $(\mathrm{cm} / \mathrm{kg})$ & $0,63 \pm 0,4$ & $0,59 \pm 0,09$ & $0,003 *$ \\
\hline
\end{tabular}

*significant difference between the two tests

\subsection{Body Composition}

Results of body composition were shown in Table 3 . None of the measurements showed significant difference between two the two test occasions.

Table 3. Comparison of body composition (Mean $\pm S D)$

\begin{tabular}{cccc}
\hline & First test & Second test & P-value \\
\hline Bone mineral density (\%) & $113,75 \pm 4,57$ & $117,25 \pm 6,95$ & 0,21 \\
Muscle Mass (kg) & $67,18 \pm 11,79$ & $66,83 \pm 11,22$ & 0,53 \\
Fat mass (kg) & $9,9 \pm 2,02$ & $10,9 \pm 1,64$ & 0,32 \\
Muscle percentage (\%) & $83,21 \pm 0,82$ & $82,68 \pm 2,11$ & 0,72 \\
Fat percentage (\%) & $12,25 \pm 0,54$ & $14,18 \pm 1,91$ & 0,19 \\
\hline
\end{tabular}

\subsection{Personal Competition Record}

Personal competition record was shown in Table 4. At group level, the one year physical training did not significantly change personal competition record.

Table 4. Personal competition record (win percent)

\begin{tabular}{lcccc}
\hline & $\begin{array}{c}\text { Before } \\
\text { first test }\end{array}$ & $\begin{array}{c}\text { Before } \\
\text { second test }\end{array}$ & $\begin{array}{c}\text { One year before } \\
\text { the first test }\end{array}$ & $\begin{array}{c}\text { One year before } \\
\text { the second test }\end{array}$ \\
\hline $\begin{array}{l}\text { Subject } \\
1^{*}\end{array}$ & 80 & 81 & 75 & 50 \\
$\begin{array}{l}\text { Subject } \\
2^{*}\end{array}$ & 80 & 80 & 100 & - \\
$\begin{array}{l}\text { Subject } \\
3^{*}\end{array}$ & 59 & 73 & 50 & 100 \\
$\begin{array}{l}\text { Subject } \\
4^{*}\end{array}$ & 57 & 56 & 66 & 50 \\
$\begin{array}{l}\text { Subject } \\
5^{*}\end{array}$ & 100 & 100 & - & - \\
Average* & $77 \pm 0.16$ & $76 \pm 0.16$ & 78 & 75 \\
\hline
\end{tabular}

\section{Discussion}

The present study revealed the physiological characters of MMA athletes. The one year routine physical training 
did not significantly improve either the physiological parameters or the personal competition record.

\subsection{Aerobic Capacity}

The full length of a MMA competition is 15 or 25 minutes, a typical aerobic sport [7]. However, MMA athletes often execute short duration of series intensive actions such as punches, kicks, knees. The energy supply of MMA has been suggested to be similar with repeated sprints; lactate system contributed $40 \%$ of the energy at the first sprint but dropped to $9 \%$ when repeated 10 times. In the meanwhile, the oxidative metabolism contributed $<10 \%$ energy at the first sprint but accounted for $40 \%$ of the energy needed at the last sprint [11]. Similarly, energy supply switch from initial anaerobic system to aerobic system has also been observed in Muay Thai fighters [12].

Because MMA athletes often execute short duration of series intensive actions, therefore, it highly stresses the lactate energy system [8]. However, if the system is stressed too much and/or too early during a competition, it may cause accumulation of metabolites like $[\mathrm{H}+][13,14]$ and subsequent acidosis [15], leading to the athletes "gas out".

As shown in Fig. 5, fully lactate recovery takes more than 10 minutes. Because the rest period between two consecutive rounds in MMA is only 1 minute, a primary utilization of the lactate energy system indicates no chance of lactate recovery between rounds, thus fatigue early and loss of competition. Therefore, even though anaerobic capacity is very important in MMA, high aerobic capacity guarantees to sustain an intensive competition.

In the study, the relative $\mathrm{VO}_{2 \max }$ for the five subjects was around $60 \mathrm{ml} / \mathrm{min} / \mathrm{kg}$ (on treadmill). Currently, there is no available study on MMA to compare our results; however this value is higher than amateur MMA fighters $(55.5 \pm 7.3$ $\mathrm{ml} / \mathrm{min} / \mathrm{kg}$; [6]) and wrestlers $(56.8 \pm 3.8 \mathrm{ml} / \mathrm{min} / \mathrm{kg}$; [17]), but resembles senior amateur boxers $(61.7 \pm 9 \mathrm{ml} / \mathrm{min} / \mathrm{kg})$ [16].

In addition to $\mathrm{VO}_{2 \max }$, the percentage of $\mathrm{VO}_{2 \max }$ usage (threshold) is another important parameter in evaluating aerobic capacity. High $\mathrm{VO}_{2 \max }$ level but low threshold indicates recruitment of the lactate energy system too early and too much, thus early fatigue in competition. In contrast, high $\mathrm{VO}_{2 \max }$ level and high threshold will postpone the activation of the anaerobic system, thus, less fatiguing metabolites accumulation and prolonged highly competition.

As shown in Fig. 1 and 3, the $\mathrm{VO}_{2}$ at AT level was around 1.5 to $4.5 \mathrm{l} / \mathrm{min}$, around 40 to $90 \%$ of $\mathrm{VO}_{2 \max }$ (appendix 3 and 4), depending on threshold measurements and test methods (treadmill running or arm cycling). The threshold level observed in the study was similar to the level of physically active individuals, but lower than high aerobic training athletes [18].

Variation in heart rate at AT level followed the same trend as $\mathrm{VO}_{2}$ at AT level for both test methods (treadmill running and arm cycling). Between the two test occasions, neither $\mathrm{VO}_{2}$ nor heart rate at AT level showed any significant difference. The results together with the $\mathrm{VO}_{2 \max }$ measurements indicate the one year routine physical training did not further improve the aerobic capacity in the MMA athletes or the MMA athletes had already reached their optimal aerobic level required for MMA.

\subsection{Anaerobic Capacity}

The anaerobic energy system, especially the ATPphosphocreatine (PCr) energy system is very important for MMA athletes because a powerful take-down or strike in MMA often means the end a competition. The results of strength and power tests (Table 2) showed a trend of decrease in the second test occasion compared with the first one, although only in two parameters. Similar as the aerobic capacity, the anaerobic test results may also indicate that the MMA athletes had already reached their optimal anaerobic level required for MMA or the energy system was not further improved by the one year training.

As shown in Fig. 5, immediately after both test occasions using both treadmill and arm cycle, all subjects reached high blood lactate levels $(9-12 \mathrm{~mm} / \mathrm{L})$, and by $2-3 \mathrm{~min}$ after the tests, blood lactate levels were even higher. In addition, all subjects reached OBLA level $(4 \mathrm{~mm} / \mathrm{L})$ and could keep working for extended periods, indicating that the subjects had a high anaerobic and acidosis tolerance/buffering capacity.

The AT values were higher measured on treadmill in both test occasions compared to values measured using arm cycle. Nevertheless, the AT level measured on arm cycle still reached around $60 \%$ of $\mathrm{VO}_{2 \max }$, indicating a high buffering capacity/acidosis tolerance in upper bodies of the MMA athletes.

\subsection{Body Composition}

The muscle mass was not significantly changed by the one year training; however, the bone density and fat mass were significantly increased in the second test compared to the first test. The increased fat mass might contribute to the decreased relative strength and power, and affect AT as well. At present it is unclear whether the changes in body composition were associated with personal competition record, but it is worth notice that MMA fighters are used to body composition changes of either long or short term before a competition.

In summary, the subjects in the study presented above average aerobic capacity, but rather high anaerobic capacity and threshold levels compared with other similar sports. The one year routine physical training did not significantly improve the physiological parameters, which was consistent with personal competitive records. This may indicate that the subjects had already reached their optimal physiological level required for MMA or the one year physical training was not effective enough to induce significant improvement in the physiological parameters. 
We have to notice that MMA athletes usually don't have a standardized on/off season as other sports, suggesting that they might be in different stages of preparation for upcoming competitions. This probably exerts high impact on the test results. The author recognized the low numbers of subjects as a limitation of the study design.

\section{Conclusions}

On basis of the current results, the following conclusions were made:

1) The MMA-fighters had above average aerobic capacity $\left(\mathrm{VO}_{2 \max }\right.$ of $\left.60 \mathrm{ml} / \mathrm{min} / \mathrm{kg}\right)$ and a high lactate tolerance and $\mathrm{H}+$ buffering capacity.

2) The one year regular physical training did not result in significant improvement in the physiological parameters, a consistent result with the personal competition records.

Appendix 1. Threshold values using treadmill

\begin{tabular}{|c|c|c|c|}
\hline & $\begin{array}{c}\text { First test } \\
(\text { Mean } \pm \text { SD) } \\
\end{array}$ & $\begin{array}{c}\text { Second test } \\
(\text { Mean } \pm \text { SD) }\end{array}$ & P-value \\
\hline $\mathrm{VO}_{2 \max }(1 / \mathrm{min})$ & $5 \pm 0,65$ & $4,85 \pm 0,57$ & 0,18 \\
\hline $\begin{array}{l}\text { Relative } \mathrm{VO}_{2 \max } \\
(\mathrm{ml} / \mathrm{min} / \mathrm{kg})\end{array}$ & $62,75 \pm 4,86$ & $60,5 \pm 5,07$ & $0,018 *$ \\
\hline $\mathrm{Hb}(\mathrm{mg} / \mathrm{l})$ & $147,25 \pm 6,56$ & $155 \pm 11,58$ & 0,22 \\
\hline [La] 0min aw (mMol/l) & $12,27 \pm 4,8$ & $10,66 \pm 4,91$ & $0,002 *$ \\
\hline [La] 3min aw (mMol/l) & $14,63 \pm 1,66$ & $14,2 \pm 3,71$ & 0,76 \\
\hline [La] $5 \mathrm{~min}$ aw $(\mathrm{mMol} / \mathrm{l})$ & $15,27 \pm 1,59$ & $14,59 \pm 4,53$ & 0,74 \\
\hline [La] 10min aw (mMol/1) & $14,57 \pm 1,71$ & $14,02 \pm 5,16$ & 0,81 \\
\hline $\begin{array}{l}\mathrm{VO}_{2} @ \text { Aerobic Threshold } \\
\text { (vent) (1/min) }\end{array}$ & $1,8 \pm 0,23$ & $1,78 \pm 0,05$ & 0,86 \\
\hline $\begin{array}{l}\mathrm{VO}_{2} @ \text { Anaerobic } \\
\text { threshold Wassermann } \\
(1 / \mathrm{min})\end{array}$ & $3,63 \pm 0,48$ & $3,4 \pm 0,86$ & 0,4 \\
\hline $\mathrm{VO}_{2} @$ Lactate $2 \mathrm{mMol} / 1$ & $3,25 \pm 0,78$ & $2,65 \pm 0,83$ & 0,2 \\
\hline $\mathrm{VO}_{2} @$ OBLA & $4,1 \pm 0,86$ & $3,85 \pm 0,85$ & 0,06 \\
\hline $\mathrm{VO}_{2} @ \mathrm{RER} 1$ & $4,4 \pm 0,87$ & $4,2 \pm 0,66$ & 0,44 \\
\hline $\begin{array}{l}\text { HR@Aerobic threshold } \\
\text { (vent) (bpm) }\end{array}$ & $114,2 \pm 10,09$ & $\begin{array}{c}116,25 \pm \\
12,58\end{array}$ & 0,3 \\
\hline $\begin{array}{l}\text { HR@Anaerobic threshold } \\
\text { Wasserman (bpm) }\end{array}$ & $155,6 \pm 10,02$ & $155,25 \pm 14,5$ & 0,17 \\
\hline $\begin{array}{l}\text { HR@ Lactate 2mMol/1 } \\
\text { (bpm) }\end{array}$ & $146,8 \pm 4,44$ & $142,75 \pm 8,34$ & 0,1 \\
\hline HR@OBLA (bpm) & $172 \pm 8,49$ & $166,25 \pm 7,93$ & 0,79 \\
\hline HR@RER 1 (bpm) & $179,5 \pm 6,86$ & $176,75 \pm 6,9$ & 0,91 \\
\hline
\end{tabular}

* - statistical significant

Appendix 2. Threshold values using arm cycle

\begin{tabular}{lllr}
\hline & $\begin{array}{l}\text { First test } \\
(\text { Mean } \pm \text { SD) }\end{array}$ & $\begin{array}{l}\text { Second test } \\
(\text { Mean } \pm \text { SD) }\end{array}$ & P-value \\
\hline $\mathrm{VO}_{2 \max }(1 / \mathrm{min})$ & $3,68 \pm 0,67$ & $3,32 \pm 0,61$ & 0,07 \\
$\begin{array}{l}\mathrm{Relative} \mathrm{VO}_{2 \max } \\
(\mathrm{ml} / \mathrm{min} / \mathrm{kg})\end{array}$ & $45,8 \pm 2,87$ & $41,15 \pm 4,06$ & $0,02 *$ \\
\hline
\end{tabular}

\begin{tabular}{|c|c|c|c|}
\hline $\begin{array}{l}\mathrm{VO}_{2} @ \text { Aerobic threshold } \\
\text { (vent) }(1 / \mathrm{min})\end{array}$ & $1,25 \pm 0,24$ & $1,33 \pm 0,5$ & 0,63 \\
\hline $\begin{array}{l}\mathrm{VO}_{2} @ \text { Anaerobic } \\
\text { threshold Wasserman } \\
(1 / \mathrm{min})\end{array}$ & $1,5 \pm 0,32$ & $1,87 \pm 0,77$ & 0,23 \\
\hline $\mathrm{VO}_{2} @ \operatorname{RER} 1$ (1/min) & $2,3 \pm 0,77$ & $2,15 \pm 0,76$ & 0,51 \\
\hline [La] 0min aw (mMol/l) & $9,53 \pm 4,88$ & $10,23 \pm 2,77$ & 0,64 \\
\hline [La] 3min aw $(\mathrm{mMol} / \mathrm{l})$ & $13,49 \pm 2,84$ & $10,59 \pm 1,43$ & 0,32 \\
\hline [La] $5 \mathrm{~min}$ aw $(\mathrm{mMol} / \mathrm{l})$ & $12,49 \pm 3,35$ & $10,12 \pm 3,77$ & 0,22 \\
\hline [La] 10min aw (mMol/l) & $10,9 \pm 3,13$ & $8,9 \pm 1,71$ & 0,07 \\
\hline $\begin{array}{l}\text { HR @ Aerobic threshold } \\
\text { (vent) (bpm) }\end{array}$ & $121,2 \pm 9,2$ & $122,5 \pm 11,09$ & 0,49 \\
\hline $\begin{array}{l}\text { HR @ Anaerobic } \\
\text { threshold Wasserman } \\
\text { (bpm) }\end{array}$ & $133,4 \pm 12,68$ & $135 \pm 17,7$ & 0,465 \\
\hline HR @ RER 1 (bpm) & $154,2 \pm 18,06$ & $146 \pm 15,44$ & 0,87 \\
\hline
\end{tabular}

* - statistical significant

Appendix 3. Threshold using treadmill (relative to the maximum)

\begin{tabular}{|c|c|c|c|}
\hline & $\begin{array}{l}\text { First test } \\
(\text { Mean } \pm \text { SD) }\end{array}$ & $\begin{array}{l}\text { Second test } \\
(\text { Mean } \pm \text { SD) }\end{array}$ & $\begin{array}{l}\text { P- } \\
\text { value }\end{array}$ \\
\hline $\begin{array}{l}\text { Aerobic threshold (vent) } \\
(\% \mathrm{mHR})\end{array}$ & $63,19 \pm 7,7$ & $63,04 \pm 9,1$ & 0,916 \\
\hline $\begin{array}{l}\text { Anaerobic threshold } \\
\text { Wasserman (\% mHR) }\end{array}$ & $82,22 \pm 7,22$ & $83,79 \pm 6,34$ & 0,76 \\
\hline $\begin{array}{l}\text { Lactate } 2 \mathrm{mMol} / 1(\% \\
\text { mHR })\end{array}$ & $78,94 \pm 5,15$ & $77,15 \pm 4,83$ & 0,42 \\
\hline RER 1 (\% mHR) & $94,75 \pm 2,1$ & $94,17 \pm 1,29$ & 0,647 \\
\hline OBLA ( $\% \mathrm{mHR})$ & $92,34 \pm 1,64$ & $89,8 \pm 3,37$ & 0,091 \\
\hline $\begin{array}{l}\text { Aerobic threshold (vent) } \\
\left(\% \mathrm{mVO}_{2}\right)\end{array}$ & $35,8 \pm 0,96$ & $37,13 \pm 5,3$ & 0,635 \\
\hline $\begin{array}{l}\text { Anaerobic threshold } \\
\text { Wasserman }\left(\% \mathrm{mVO}_{2}\right)\end{array}$ & $72,43 \pm 7,63$ & $69,48 \pm 11,69$ & 0,598 \\
\hline $\begin{array}{l}\text { Lactate } 2 \mathrm{mMol} / 1(\% \\
\mathrm{mVO} 2)\end{array}$ & $63,99 \pm 11,44$ & $54,01 \pm 13,65$ & 0,237 \\
\hline RER $1\left(\% \mathrm{mVO}_{2}\right)$ & $90,59 \pm 6,46$ & $89,25 \pm 1,63$ & 0,68 \\
\hline OBLA $\left(\% \mathrm{mVO}_{2}\right)$ & $80,99 \pm 8,8$ & $81,40 \pm 9,07$ & 0,762 \\
\hline
\end{tabular}

(\%mHR) - percent of maximal HR

$\left(\% \mathrm{mVO}_{2}\right)$ - percent of maximal $\mathrm{VO}_{2}$

Appendix 4. Threshold using arm cycle (relative to the maximum)

\begin{tabular}{|c|c|c|c|}
\hline & $\begin{array}{l}\text { First test } \\
(\text { Mean } \pm \text { SD })\end{array}$ & $\begin{array}{l}\begin{array}{l}\text { Second test } \\
(\text { Mean } \pm \text { SD) }\end{array} \\
\end{array}$ & $\begin{array}{l}\text { P- } \\
\text { value }\end{array}$ \\
\hline $\begin{array}{l}\text { Aerobic threshold (vent) } \\
\text { (\%mHR) }\end{array}$ & $64,82 \pm 7,04$ & $66,37 \pm 8,16$ & 0,255 \\
\hline $\begin{array}{l}\text { Anaerobic threshold } \\
\text { Wasserman (\%mHR) }\end{array}$ & $69,37 \pm 6,52$ & $73,71 \pm 12,49$ & 0,284 \\
\hline RER 1 (\%mHR) & $81,58 \pm 10,01$ & $79,37 \pm 11,70$ & 0,736 \\
\hline $\begin{array}{l}\text { Aerobic threshold (vent) } \\
\left(\% \mathrm{mVO}_{2}\right)\end{array}$ & $34,07 \pm 4,17$ & $39,29 \pm 8,71$ & 0,269 \\
\hline $\begin{array}{l}\text { Anaerobic threshold } \\
\text { Wasserman }\left(\% \mathrm{mVO}_{2}\right)\end{array}$ & $41,57 \pm 5,95$ & $54,84 \pm 12,15$ & 0,111 \\
\hline RER $1\left(\% \mathrm{mVO}_{2}\right)$ & $58,63 \pm 16,47$ & $63,6 \pm 11,46$ & 0,583 \\
\hline
\end{tabular}

(\%mHR) - percent of maximal HR

$\left(\% \mathrm{mVO}_{2}\right)$ - percent of maximal $\mathrm{VO}_{2}$

\section{References}

[1] C. P. McLellan, D. I. Lovell and G. C. Gass, Performance analysis of elite Rugby League match play using global positioning systems. J Strength Cond Res. 2011, vol. 25, Jun, 
pp. $1703-10$.

[2] J. Yoon. Physiological profiles of elite senior wrestlers. Sports Med. 2002, vol. 32, pp. 225-33.

[3] W. J. Kraemer, A. C. Fry, M. R. Rubin, T. Triplett-McBride, S. E. Gordon, L. P. Koziris, et al., Physiological and performance responses to tournament wrestling. Med Sci Sports Exerc, 2001, vol. 33, Aug, pp. 1367-78.

[4] B. Mirzaei, D. B. Curby, F. Rahmani-Nia and M. Moghadasi. Physiological profile of elite Iranian junior freestyle wrestlers. J Strength Cond Res, 2009, vol. 23, Nov, pp. 2339-44.

[5] E. Franchini, F. B. Del Vecchio, K. A. Matsushigue and G. G. Artioli, Physiological profiles of elite judo athletes. Sports Med, 2011, vol. 41, Feb. pp. 147-66.

[6] M. Schick, L. Brown, J. Coburn, W. Beam, E. Schick and N. Dabbs, Physiological Profile of Mixed Martial Artists. Medicina Sportiva, 2010, vol. 14, pp. 182-187.

[7] P. O. Åstrand, K. Rodahl, H. A. Dahl and S. B. Strömme, Textbook of Work Physiology, $4^{\text {th }}$ edition. Human Kinetics. Champaign, USA. 2003.

[8] J.A. Amtmann, K.A. Amtmann and W.K. Spath, Lactate and rate of perceived exertion responses of athletes training for and competing in a mixed martial arts event. Journal of Strength \& Conditioning Research, 2008, vol. 22, pp. 645-7.

[9] R. B. Mazess, H. S. Barden,J. P. Bisek and J. Hanson, Dualenergy $\mathrm{x}$-ray absorptiometry for total-body and regional bone-mineral and soft-tissue composition. Am J Clin Nutr, 1990, vol. 51, Jun, pp. 1106-12.

[10] P. Butudom, J. H. Foreman, K. H. Kline and E. L. Whittem, Validation and comparison of two methods of measuring lactate in equine plasma. Equine Vet J, 2010, vol. 42, Nov, Suppl., pp. 155-60.

[11] O. Girard, A. Mendez-Villanueva and D. Bishop. Repeatedsprint ability - part I: factors contributing to fatigue. Sports Med, 2011, vol. 41, Aug, pp. 673-94.

[12] A. Crisafulli, S. Vitelli, I. Cappai, R. Milia, F. Tocco, F. Melis and A. Concu, Physiological responses and energy cost during a simulation of a Muay Thai boxing match. Appl Physiol Nutr Metab, 2009, vol. 34, Apr., pp. 143-50.

[13] D. Bishop, S. Lawrence and M. Spencer. Predictors of repeated-sprint ability in elite female hockey players. J Sci Med Sport, 2003, vol. 6, Jun, pp. 199-209.

[14] S. Ratel, C. A. Williams, J. Oliver and N. Armstrong, Effects of age and recovery duration on performance during multiple treadmill sprints. Int J Sports Med, 2006, vol. 27, Jan, pp. 1-8.

[15] K. Sahlin, R. C. Harris, B. Nylind and E. Hultman, Lactate content and $\mathrm{pH}$ in muscle obtained after dynamic exercise. Pflugers Arch, 1976, vol. 28, Dec, pp. 143-9.

[16] G. L. Khanna and I. Manna, Study of physiological profile of Indian boxers. Journal of Sports Science and Medicine, 2006, vol. 5, pp. 90-98.

[17] I. Barbas. G. Fatouros, I. I. Douroudos, A. Chatzinikolaou, Y. Michailidis, D. Draganidis and et al., Physiological and performance adaptations of elite Greco-Roman wrestlers during a one-day tournament. Eur J Appl Physiol, 2011, vol. 111, Jul., pp. 1421-36.

[18] D. L. Wilmore and J. H. Costill. Physiology of sport and exercise. 2nd edition. Champaign (IL): Human Kinetics, 1999. 